\title{
THE IMAGO PRIMI SAECULI SOCIETATIS IESV (1640). DEVOTION, POLITICS AND THE EMBLEM
}

\author{
EL IMAGO PRIMI SAECULI SOCIETATIS IESV (1640). DEVOCIÓN, POLÍTICA \\ Y EL EMBLEMA
}

\author{
Pedro F. Campa \\ University of Tennessee at Chattanooga
}

ABSTRACT: The Imago Primi Saeculi Societatis Iesv (1640) is, perhaps, the most beautiful book of emblems published by the Jesuits in the seventeenth century. The book is a festive commemoration offered by the priests and students of the Flemish-Belgian Province in celebration of the centenary of the founding of the Society of Jesus. The work includes 127 full-page emblems distributed throughout a total of 956 folio-sized pages that narrate and illustrate in emblematic fashion the foundation, development, vicisstitudes and achievements of the Socirty in its evangelical and pedagogical mission. From the moment of its publication, the Imago was the object of attacks by Huguenauts and Jansenists who criticized its haughtiness, grandiloquent language and the hyperbolic comparisons of the narration. Hidden behind this criticism were the reasons for the Jansenist offensive against the book. Probabilism, the supposed frivolous attitude towards confession and the frequency of communion, advocated by the Jesuits, was the object of a pair of insulting treatises directed against the Imago by the famous Jansenists Antoine Arnauld and Issac Louis le Maitre de Sacy. The critics of the Imago maliciously ignored that the book's grandiloquent style, appropriate to a jubilation celebration, conforms to the language of classical rhetoric, thus perpetuating the propagandistic image of the book.

KEYWORDS: Imago Primi Saeculi, Society of Jesus, Flanders, Flemish-Belgian Province.

RESUMEN: El Imago Primi Saeculi Societatis Iesv (1640) es quizás el libro de emblemas más bello publicado por los jesuitas en el siglo xvII. El libro es una conmemoración festiva ofrecida por los sacerdotes y los escolares de la Provincia Flandro-Belga que celebra el centenario de la Compañía de Jesús. La obra contiene ciento veintisiete emblemas a plena página con un total de novecientas cincuenta y seis páginas en folio que narran e ilustran de manera emblemática la fundación, el desarrollo, las vicisitudes y los logros de la Compañía en su misión evangélica y docente. Desde su publicación, el Imago fue blanco de los ataques de hugonotes y jansenistas que criticaban la soberbia, el lenguaje grandilocuente, y las comparaciones hiperbólicas de la narrativa. Detrás de la crítica, se escondían las razones de la ofensiva jansenista hacia el libro. El probabilismo, la supuesta actitud frívola hacia la confesión, y la frecuencia de la comunión, aconsejada por los jesuitas, fueron objeto de sendos tratados injuriosos contra el Imago por parte de los famosos jansenistas Antoine Arnauld e Issac Louis le Maître de Sacy. Los críticos del Imago maliciosamente descontaron que el estilo grandilocuente del libro, propio del jubileo, se ajusta al lenguaje de la retórica clásica, perpetuando así la imagen propagandística del libro.

PALABRAS CLAVES: Imago Primi Saeculi, Compañía de Jesús, Flandes, Provincia Flandro-Bélgica.

Fecha recepción: 20-8-2017 / Fecha aceptación: 27-9-2017 
Perhaps the most beautiful emblem book produced in the seventeenth century, and without a doubt, among the most attractively illustrated imprint produced in the Low Countries, is the celebratory volume commemorating the one-hundredth anniversary of the founding of the Society of Jesus. The Imago Primi Saeculi Societatis Iesv was published in Antwerp in 1640. The book was composed by Jesuits and their students in the Flandro-Belgian province of the Society as homage to the founders of the Order as well as a record of spiritual and material achievements of its members on behalf of the Church (Daly and Dimler, 1997: I, 56-57). One of the many emblem books produced by Jesuits in the seventeenth century, the Imago became the target of virulent attacks against the public image of the Society in France and abroad.

These attacks, fueling envy against the Society, had begun in 1603 during the reign of Henri IV, when the Jesuits were allowed to return to France since their expulsion by the Parlement de Paris in 1594. The offensive acquired a new impetus as Jansenists and Calvinists joined the ranks as enemies of the Jesuits. Some of the causes of animosity against the Society were the ostensible pride in its evangelizing accomplishments (which was perceived as arrogance), the preponderance of Jesuits as royal advisers and confessors, the alleged laxity and casuistry of Jesuits' confessional methods, and the envy over the ever-increasing success of Jesuit colleges. Even if the Imago did not directly address some these issues, the book became the most visible target for attacks against the Society of Jesus.

The Jesuits had a long history in France before the publication of the Imago. By virtue of the Edict of Rouen (January 2, 1604), the Society was allowed to return and resume their pastoral and educational mission in France with a number of restrictions and fewer concessions than those granted to other religious orders. These restrictions did not sit well with the then General Claudio Acquaviva who was hesitant to accept the terms for the re-establishment of the Society (Nelson, 2005: 102). Finally the terms of the Edict were accepted because in reality Henri IV's intention was to keep the Society under royal patronage rather than to follow the restrictions imposed by the agreement. The Society became a powerful ally of the throne in the efforts of conversion of Calvinists and the Jesuits enjoyed a broader support amongst French Bishops than before the expulsion (Nelson, 2005: 127). In 1608, Henri IV lifted the prohibition of against foreign Jesuits to residing France, so the Society could deal with the shortage of qualified teachers (Nelson, 2005: 113). In 1603 the founding of the College of La Flèche under royal patronage was followed by the opening and/or re-establishing of Jesuit colleges at Aix, Amiens, Billom, Bourges, Caen, Cahors, Châlons, Rennes, Tours and Troyes. Local patronage and private endowments played a part in the founding and support of the colleges and by 1610, the Society was the largest single organization educating the Catholic elite in France (Nelson, 2005: 123). During the reign of Louis XIII, the Jesuits continued to be well connected with the king and his powerful first minister, Cardinal Richelieu. Early on, the Cardinal saw in the Society a most useful weapon against heresy and a powerful component of the educational mission of the realm. The Jesuit General Vitelleschi and Richelieu continued to be on good terms in spite of conflicts regarding some of the king's Jesuit confessors. When the Charenton Calvinist pastors demanded the abolition of the Society in Europe, the Cardinal retorted:

You think of annoying the Jesuits, but you help them greatly [...] it is a great glory for them to be blamed by the very mouth that accuses the Church, slanders the Saints, offends Jesus and makes God guilty [...] many love the Jesuits because you hate them. ${ }^{1}$

1. "Vous pensez nuire aux Jésuites et vous les servez grandement [...] ce leur est grande gloire d'être blâmés de la bouche meme qui accuse l'Eglise, qui calomnie les Saints, fait injure à Jésus-Christ et rend Dieu coupable [...] beaucoup les aiment partic- 
In spite of royal protection and its tangible success, the Society went through difficult times during the first half of the seventeenth century. First, their educational competence was challenged in order to prevent them from conferring degree-granting university status to some of their colleges (Bertram Hill, 1961: 17). Their disapproval of alliances with Protestants in the Low Countries to the detriment of Catholic and Imperial interests offended French patriotic sensitivities and thwarted Richelieu's plans for being on the winning side of the Thirty Years War. Nicholas Caussin S. J., who was briefly Louis XIII's confessor, tried to appeal to the king's conscience to break the alliance with Protestants. The king in turn, showed him signed affidavits, that the Cardinal had brought him that included several Jesuit signatories supporting the war effort. The Jesuit exclaimed: "Ah, Sire ils ont une église à batir» (But, Sire, they have a church to build) (Crétineau-Joly: II, 485).

Also, there was foreign and local propaganda about the harsh behavior of members of the Society in their crusade for the conversion of Protestants throughout the Empire and their alleged greed in requisitioning establishments that belonged to other religious orders. Although the Society in France tried to detach itself from debates over papal prerogatives, it often had to deal with the Gallican ideology of French bishops and conflicts involving royal power and papal supremacy where the loyalties of the Jesuits were put into question. On the issue of temporal power, the writings of foreign Jesuits (such as Bellarmine, Suárez and Mariana) about tyrannicide, placed French Jesuits on the defense as if having to justify the political opinions of their foreign confrères. In addition, throughout this period the devotional and dogmatic writings of some members of the Society were also scrutinized in the light of probabilism and casuistry and their alleged unconventional practices for the sacrament of confession. In particular, the Jansenists took issue with the Jesuits' advocacy for frequent confession and communion in their zeal to renew devotion and eucharistic practices among the Catholic faithful.

In brief, this was the political and religious climate in 1640 when the Flemish Jesuits published the Imago Primi Saeculi in the Spanish Netherlands to commemorate the hundredth anniversary of the founding of the Society. Why and how a celebratory volume written in Latin could have become the focus of such passionate and long-lived attacks among the enemies of the Society are some of the questions that this article will attempt to answer.

The authorship of the Imago is ascribed to the Jesuits and their students in the Flandro-Belgian province of the Society. Evidence reveals that the project was coordinated by Johannes Bollandus, the famous compiler of Catholic hagiography (Acta Sanctorum), who according to De Baecker-Sommervogel (1890: I, 1625) had the original idea that the book was to be a mélange of poetry, emblems and history preceded by a study about the origin and development of the classical Jubileum. The provincial in the Low Countries, Jan de Tollenaere (1582-1643) promoted the book stating that all of the orators and poets of the Flemish province had collaborated in the project. The names of Sidronius de Hossche (1596-1630) and Jakob van de Walle (1599-1690), both notable and prolific Jesuit poets and Latinists shared the authorship of the emblem subscriptions. According to Daly and Dimler (2016), The Imago appeared in the two most productive decades of Jesuit emblem book production, between 1621 and 1640, when 330 Jesuit emblem books were published.

The organization for the book, with its 127 emblems, is arranged into six sections as presented in the frontispiece which was designed by Phillipe Fruytiers and engraved by

ulièrment parce-que vous les hä̈ssez", Les principaux points de la Foi [...] défendus contre les quatre ministres de Charenton (Châlons, 1683), cit. in J. Crétineau-Joly, 1846: II, 479. 


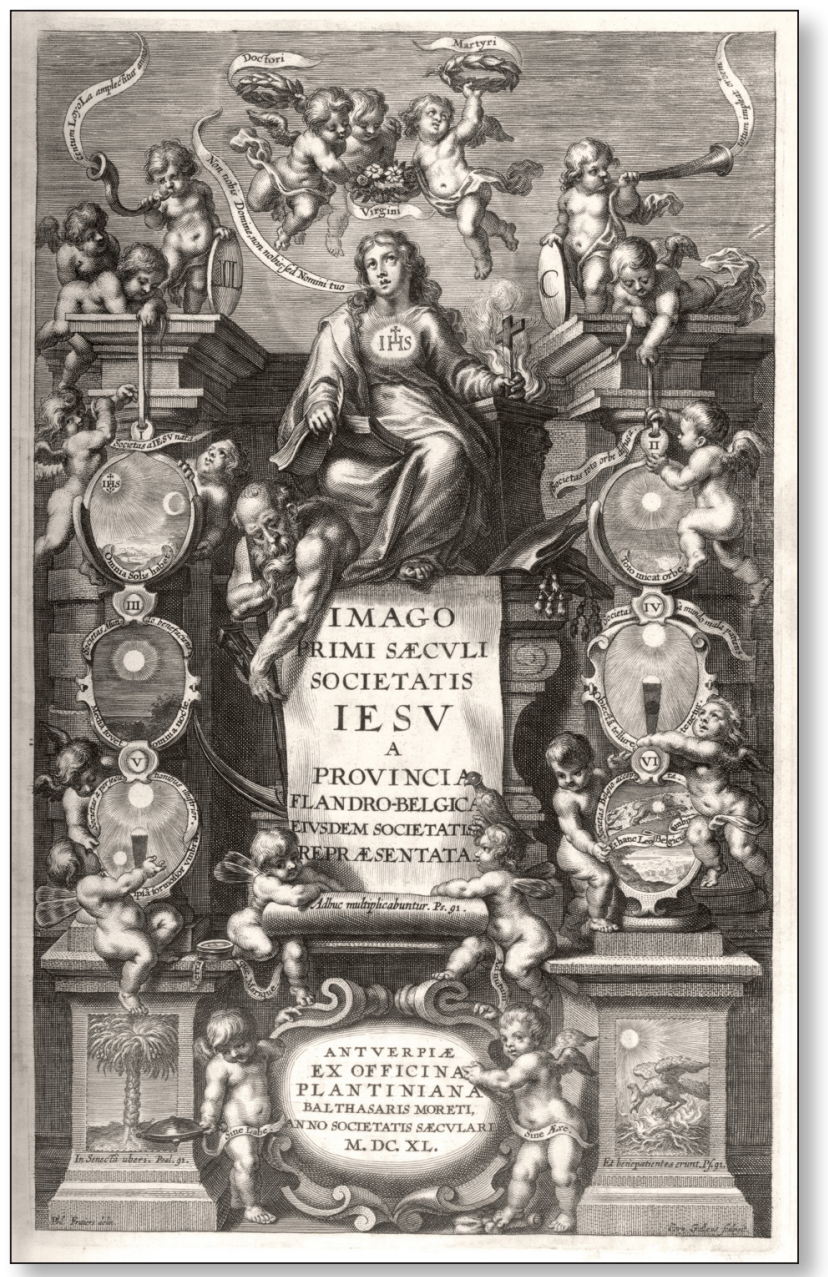

Fig. 1. Imago Primi Saeculi Societatis Iesu (1640). Frontispiece.

Cornelis Galle, the Elder. The structure of the work is schematized by the six emblems that flank a female figure with the IHS triagram on her chest uttering the words: «Not for us Lord, not for us but for your glory" (Non nobis Domine, non nobis sed Nomini tuo) [fig. 1]. ${ }^{2}$ The figure is an allegorical representation of the Society, with a pen and a book on her right hand and a cross in flames on her left. Three angelotti hover over the figure holding crowns symbolizing martyrdom, chastity, and knowledge. The escutcheons, held by putti flanking the head of the figure, one with two "L's" and one with a $" \mathrm{C} »$ represent the centenary of the Society and the two "L's" in Loyola's name respectively. Father Time, holding an hour glass and a scythe, sleeps under the right foot of the figure. Discarded, under her left foot, are the rejected symbols of Church hierarchy: a bishop's miter and a cardinal's galero. The four vows of the Jesuits are represented below by four winged genies; one holding a compass for obedience (terraque marique), the second one below, a mirror for chastity (sine labe); the next one of the left a hooded falcon (ad nutum) for papal obedience and the last genie is empty handed trampling objects under his feet (sine aere) and it represents the vow of poverty. The emblems that flank the figure are crowned by roman numerals indicating the title of each section.

The first section "Societas nascens" the birth of the Society, illustrated with 31 emblems in which the founding of the Society is compared with the birth of Christ; the second section, "Societas crescens» illustrated with 14 emblems traces the development of the Order until 1640. The third section, "Societas agens» symbolizes the deeds of the Society, as it compares it with Christ's evangelical labors, and it is illustrated with 8 emblems. The fourth section, "Societas patiens» stands for the toils and suffering of the Society and it is illustrated by 17 emblems. The fifth section, "Societas Honorata» recounts the honors received by the Society

2. The illustrations from the Imago Primi Saeculo for this article are taken from the high-resolution CD Rom images included in O' MAlley, J. (ed.) [2015]. Art Controversy and the Jesuits. The Imago Primi Saeculi (1640), Philadelphia, SJUP [Early Modern Catholicism and the Visual Arts, 12]. 
and it is illustrated by 14 emblems. Finally, the sixth section, deals with the history of the Flandro-Belgian Province of the Society for which there are 14 emblems.

In the book, the emblem clusters are preceded by occasional celebratory odes followed by lengthy narratives, panegyrics, encomia, epitaphs, elegies, orationes etc. which account for most of the book's 956 pages. The Imago ends with monumental epigraphy commending the Society under the protection of Mary and Jesus, SS. Ignatius and Francis Xavier (they were both canonized in 1622) and the Church militant, followed by an index. The privilegium to publish, dated 1640, was issued by Phillip IV of Spain and Jaan de Tollenaere, the Jesuit Flemish Provincial.

Many of the emblems of the Imago as Guido Arbizzoni ${ }^{3}$ has observed are emblematized imprese; that is imprese that had been used by a famous bearer and they have been transformed into emblems with an additional explanatory motto and subscriptio. In other cases, as R. Dimler (1981: 433-38) has observed, the picturae come from the mainstream emblematic tradition and have been pressed into service invested with a new meaning. For example, one of the imprese from Societas Agens, "In utrumque paratus», the impresa of Onofrio Panvinio illustrated in Le imprese ilustre (1584) of Girolamo Ruscelli (and also in Pietrasancta's De symbolis heroicis, 1534, p.460) with the same motto and pictura [fig. 2] in the Imago it becomes an emblem titled: "Societas et agere $\delta$ pati fortia» (the Society accomplishes and endures great deeds, Imago, p.453). The pictura shows an ox in a plowed field flanked by a sacrificial altar and a plow with the borrowed impresa motto "In utrumque paratus» (Ready for one or the other). In this case the subscriptio alludes to the sacrifices and evangelical work of the Order as well plowing in the Lord's vineyard.

In the "Prolegomena" an emblem of the palm tree appears with the motto

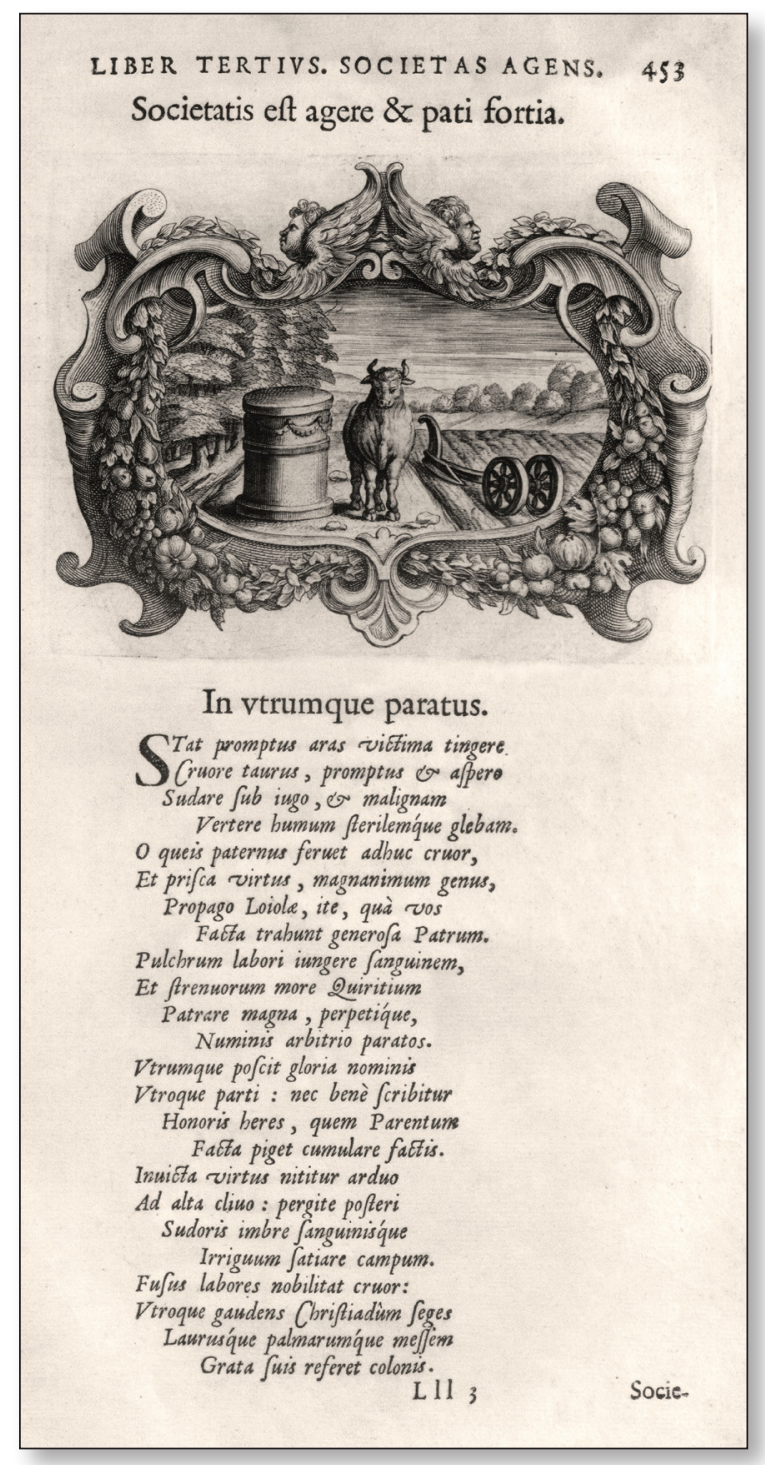

Fig. 2. Imago Primi Saeculi Societatis Iesu (1640). "Liber tertivs", 453.

3. Arbizzoni, 2007: 23-24. Van Vaeck, van Houdt and Roggen, 2015: 127-410, have tracked down the sources and analogs of the emblems in specific books. 


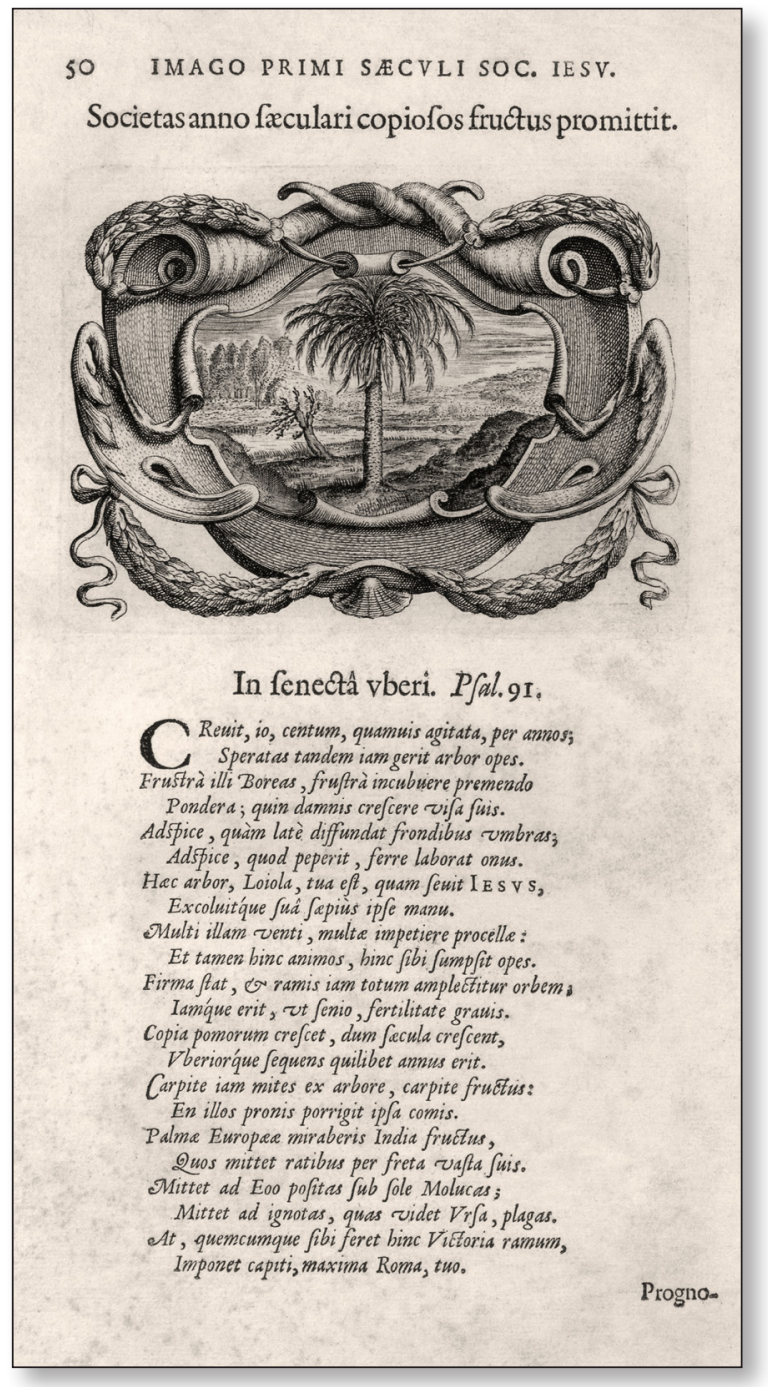

Fig. 3. Imago Primi Saeculi Societatis Iesu (1640). "Prolegomena», 50 . ry (saeculo) of resilient, unbending and fruitful activity as the palm tree standing behind the ring suggests. ${ }^{4}$

The 31 emblems of the first section "Societas nascens" (The birth of the Society) deal for the most part with the rewards of poverty, chastity, humility and obedience, the perils of ambition, the rejection of honors and Jesuit vows, including an emblem for the fourth vow "Rescipit Astrorum Regem» (It looks over the king of stars, Imago: 153) on papal obedience. The subject of the emblems in this section is complementary to the text which deals with the origins and the founding of the Society, including the outlandish notion that the Soci-

4. For the emblematic palm tree see: Chorpenning (2007: 333-347); Díaz de Bustamante (1980: 27-88); Galera Andreu (1985: 63-67). 


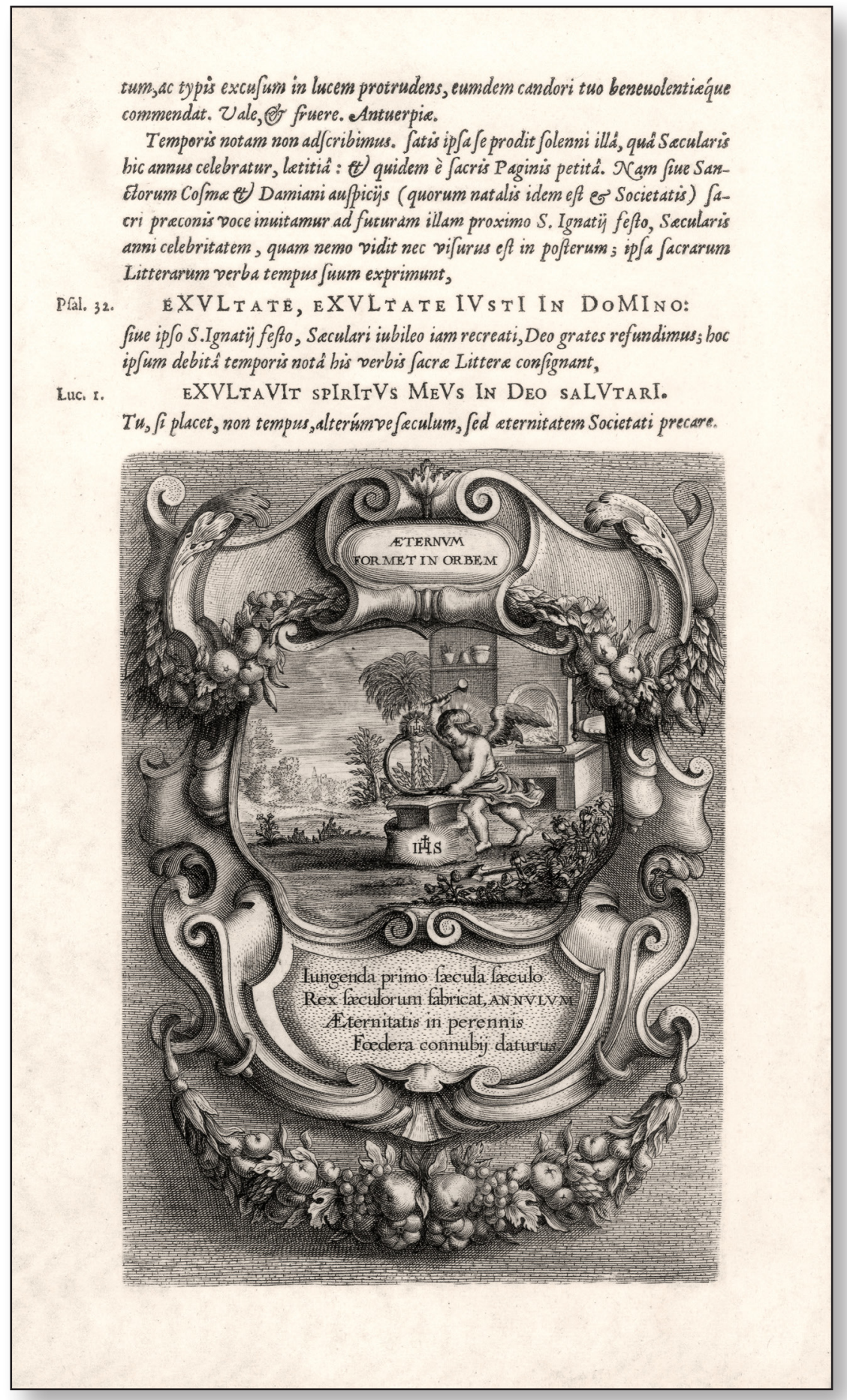

Fig. 4. Imago Primi Saeculi Societatis Iesu (1640). Preliminary, h. 4v. 


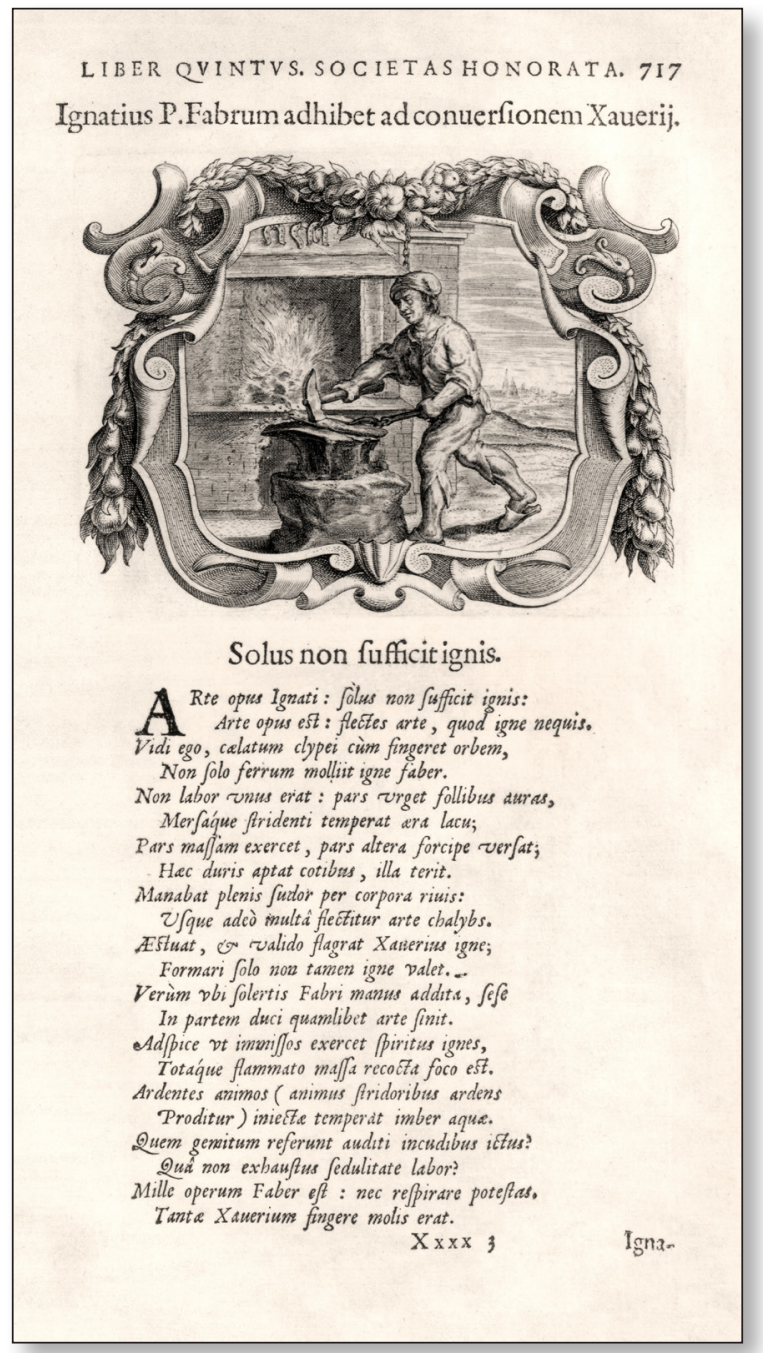

Fig. 5. Imago Primi Saeculi Societatis Iesu (1640). "Liber qvintvs», 717. ety had been foretold in the prophecies of Isaiah (Imago: 60). This statement as well as other rhetorical hyperboles in the Imago became the focus of aggressive criticism.

At a glance, there is more than meets the eye in the emblems of the Imago. Fr. Dimler in a lengthy article explored the inter-textuality of the emblems in the light of Jakob Masen's imago-figurata categories (Dimler, 1999: 279-295), where many anagrams and plays on words are found in the Latin subscriptios. An emblem from the fifth Section, "Societas Honorata», the emblem concerning Peter Fabre [fig. 5] «Ignatius P. Fabrum adhibet ad conversionem Xaverii» (Ignatius uses Peter Fabre to convert Francis Xavier $)^{5}$ is a suitable example. The pictura shows a blacksmith pounding hot iron from a forge on an anvil (Imago: 717); the motto reads "Solus non sufficit ignis» (Fire alone is not enough). In this emblem, the recruitment of Francis Xavier by Peter Favre, and Ignatius himself, is the object of an ingenious play on words with "faber", the Latin word for smith and "ignis», the word for fire which is the first syllable for the name Ignatius. (The craftsman did not melt the iron by fire alone/ It was not simply one effort) "Non solo ferum molliit igne faber/ Non labor unus erat». The blacksmith (faber) is also the Latin rendering of Favre, who was known as the «hammer of the heretics».

Fire, flames and its analogs have a long history in the allegorical and pictorial imagery for the Society. ${ }^{6}$ The symbolism here is reminiscent of Ignatius" "Ite inflammate omnia» (Go, set them on fire). In this case, to set Xavier's soul on fire "spiritus ignes», it took work, strength, constancy and art. The motto of this emblem is also an allusion to other lemmata used throughout the book. For example, «nexus not sufficit unus» (One vow is not enough) from the emblem «Renovatio votorum»

5. Fabre was instrumental in the spiritual development of Xavier. As he relates for the year 1529: «[...] dico autem maxime de magistro Francisco Xaverio, qui est de Societate Jesu. Hoc anno venit Ignatius, ut esset in eodem collegio Sanctae Barbarae et in eodem cubiculo [...]. Erat autem supradictus magister Xaverius id oneris suscepturus. Benedicta sit in aeternum Divina Providentia, quae sic ordinavit in meun bonum et salutem!» (Favre, 1873: 7).

6. There are numerous allusions and depictions of fire in the emblem picturae and mottoes; for example: «sursum rapit ignes», 719; "male luditor igne», 716; «in igne alacritas», 579; "[...] divini amoris igne concionem», 718. 
(The renewal of the vows, Imago: 199) and "unus non sufficit orbis" (one world is not enough, Imago: 26) which not surprisingly, is a motto used by the present Jesuit General, Adolfo Nicolás S. J.

Throughout the Imago there are other specific emblems honoring other Jesuit saints and blessed. Saint Ignatius and the Jesuit devise (IHS) are the subject of several emblems as well as Aloysius Gonzaga (329, 723), Stanislaus Kostka (724, 330), Francis Xavier $(720,721)$, Francis Borgia (722), Carlo Spinola $(727)$ and the Jesuit martyrs $(725,726)$.

Section "Societas agens" (Imago: 331-480) contains both in the text and the emblems the keys to the Jesuit docent and spiritual mission. In the spiritual realm, frequent confession and communion, missions, the value of The Spiritual Exercises and the encouragement and support of Marian sodalities. In the educational field, catechism instruction, the education of children, higher learning for youth and the instruction of the illiterate are illustrated by appropriate emblems.

The matter of confession and communion ${ }^{7}$ ignited serious controversies between Jansenists and the members of the Society. These issues, including the publication of the Imago, made famous by Pascal's Provinciales, brought matters to the extreme. The Jesuits were accused of casuistry and laxism when dealing with confession. Allegedly, easy absolutions and frequent communion tended to trivialize eucharistic practices and not to prepare for the sacrament with extreme contrition, prayer and abstinence (Bergin, 2009: 261-268). The truth of the matter is that in the seventeenth century Jesuit confessional practices evolved and were ahead of their time if compared to those of the French secular clergy. For example, the penitential cannons of Carlo Borromeo, translated into French and imposed upon some of the French regular clergy reads more like a medieval penitential than a post-tridentine confessional manual (Borromée, 1672). ${ }^{8}$

In the section "Societas Crescens" (in Caput X) there is an impressive list (Imago: 238-248) of the provinces, colleges, seminaries and houses (Catalogus Provinciarum Societatis Iesu, Domorum, Collegiorum [...]) as well as a list of lengthy individual epitaphs or Elogia Sepulchrarum (Imago: 280-95) celebrating the life of the founders of the Society, in large capital letters, in the manner of Imperial Roman monumental epigraphy. The list includes Ignacio de Loyola, Francisco Xavier, Diego Laínez, Simão Rodrígues, Pierre Favre, Paschasse Broët, Alfonso Salmerón, Claude Jay, Jean Codure and Nicolás Bobadilla.

No doubt that the fourth section dedicated to the suffering Society ( Societas Patiens») was meant to inspire sympathy and pity upon the readers. This section eloquently details the calumnies, persecution and expulsions endured by a blameless Society on both sides of the world as well as the blood shed by its members at the hands of pagans and heretics. The Society had been maliciously persecuted by heretics as «Superba, ambitiosa, arrogans Societas est" (Imago: 559) and had been maligned since its founding. The seventh chapter in this section specifically "Eiecta e Galliâ Societas, et restitute» (Imago: 505-511) is a rather extensive diatribe about the false accusations levied against the Society by members of the Parliament of Paris and the Sorbonne who allegedly conspired with foreign agents to in or-

7. Antoine Arnauld treatise of frequent communion allegedly keep many faithful away from the sacrament: "[...] c'est un grand peché de s'approcher de cette Table Sainte, \& cette Hostie terrible, comme parlent les Pères, sans la disposition necessaire pour une action si sublime $\delta$ si divine [...]» (1644: 30).

8. For example, aside from assigning specific atonement for each sin (e.g. ten years of penance for apostasy), Borromeo recommends for parish priests to keep a detailed chart for each family and to monitor parish attendance, behavioral changes, fasting, etc. Lyn Martin (1988: 233), contends that the Jesuits "revealed a flexible mind, not restricted to tradition and regulation, but open to modification by experience, a mentality promoted by the recurrent advice contained in Loyola's Constituttions [...]». 
der to secure the banishment of the Jesuits from France. As one reads through this section, the feeling is evident that nothing has been forgotten.

In 1640, when Bishop Cornelius Janssen's Augustinus was posthumously published, the Jesuits took it as a personal affront that the book appeared on the centennial of their Order Strayer, 2012: 59). The followers of bishop Janssen were Catholic rigorists concerned with the primacy of grace versus free will. In the Jansenists' minds, the only chance for salvation is a grace not freely granted by God since presumably Christ did not come to save the whole world but a chosen few. The Jansenists' rebellious austerity favored simplicity, seclusion, individuality and constant prayer. ${ }^{9}$ They also supported the prerogatives of Gallicanism vis-à-vis papal supremacy. The Arnauld family, sworn enemies of the Society, almost single-handedly ran the Jansenist establishment of Port Royal which attracted notable people, like Blaise Pascal, Antoine Le Maistre, Pierre Nicole, Louis-Issac Lemaistre de Sacy, and Jean Racine among others, to their circle. Jesuits attacked Jansenists on principle since their ideas had been censured by Rome and their rigorism on matters of attrition, absolution and frequent communion was diametrically opposed to the Jesuit mission for the conversion of Protestants and the renewal of the Faith. Even though Jansenism had a strong whiff of Calvinism, it had many sympathizers among devout Catholics and main-stream bishops because of its questioning of papal supremacy and the austere life style and devotional practices of its followers.

Curiously enough, the first controversy concerning the Imago did not emerge from the Jansenists, but from the theology faculty of the University of Louvain who examined the book -especially section six concerning the Flandro-Belgian Province- (Salviucci, 2010: $616)$ to see if the book had faithfully reported the controversies around Fr. Leonardus Lessius' (1554-1623) teachings on matters of grace and predestination. Lessius appears in the Imago $(17,847-8,877)$ as having been supported by the Society as well as by the Louvain faculty, who favored Augustinian views in matters of grace, in spite of several controversial issues. The issue seemed settled when Rome prohibited further polemic on the matter in 1588. However, as late as 1610, General Acquaviva wrote Lessius:

[...] what seems most difficult is that against the authority of St. Augustin and of Cardinal Bellarmine, Fr. Suárez and the other theologians of the Society, your Reverence does not admit that God does more in favor of the predestined than for others, as if there was only one common grace, sufficient for all, so that God granted the chosen no more than what he gave the condemned. ${ }^{10}$

It seems that in spite of the controversies, the Flemish Jesuits wished to uphold the reputation of Lessius as a most virtuous and famous member of their province «non magis ingenii monumentis quàm virtutum famâ aeternum» (Imago: 17). During the Lessius controversy the text mentions that there were complaints to the Spanish king about the Jesuit devise (IHS)

9. "Only grace communicated in a serious life of prayer, can inaugurate the reign of virtues in the human soul. Efforts to cultivate the virtues on the basis of personal initiative are doomed to failure since the initiative itself is rooted in pride [...]. Grace cannot build on nature, since the corruption of postlapsarian humanity is so thorough" (Conley, 2009: 85).

10. "[...] reicit gratiam congruam, nec admittit. Deum facere quidquam aliud erga homines, quos salvare intendit, qua erga alios qui perduntur; sed gratiam unam esse asserit communem omnibus sufficientem [...]", Acquaviva to Lessius, Rome, 23 October 1610 (Cit. in. Le Bachelet, 1931: I, 151-152). In 1614, Cardinal Bellarmine wrote Lessius: «I approve and am glad that you have given up writing and turned your mind to reading and contemplation, for it is impossible to write anything at present without laying oneself to the cavils of either enemies or friends» (Cit. in Brodrick, 1928: II, 67). 
as immodest and boastful ( $a$ adversus nos scripta est accusatio divitiae nostrae inmodicae iactabantur [...]", Imago: 849). Also, mixed with these facts there is some venting about the maligning of the Society based on allegations of greed and self promotion «In our life how often we are beaten down; when we want to characterize someone who is miserly and greedy do we not call him a Jesuit?» ( «In vita nostrae moresque quám frequenter vapulant! Quoties avarum, quotes ambitiosum genus hominus dicimur Iesuitae?", Imago: 849).

Section six of the Imago is a history of the Flandro-Belgian Province and its missions as well as some recapitulation of items covered in previous chapters. The Low Countries, the most troublesome of the Spanish possessions in Europe was also the site of bloody encounters between Catholics and Protestants and the Spanish and the Dutch. The Jesuits, who endured persecution and banishment, were allowed to return under Alejandro Farnesio, governor of the Low Countries (1578-1592). Although brutal excesses were committed under the rule of the Duque of Alba, the Protestants are blamed for the internal struggles and the vicissitudes endured in the Low Countries in the sixteenth century ( Haereses maxima caussa miseriarum Belgii», Imago: 902).

The recovery of the Spanish provinces reaffirmed the position of the Society and under the new governor and Jesuit colleges were founded (Courtrai, Ypres, Gant, Mons, Brussels). This section celebrates the protection of the Spanish crown to the Catholic cause and to the Society and memorializes the piousness of the Spanish Habsburgs -Phillip II, Phillip IV, Don Fernando, the Cardenal Infante- (Imago: 891-898). The section ends with an oration dedicated to Petrus Canisius, «the apostle of Germany", the most famous Jesuit of the Province.

The first impressions of the Imago when it was published in 1640 came as negative rumor from the Jesuits in Rome since Bollandus himself had sent a copy to Cardinal Francesco Barberini, who gave it to his uncle Pope Urban VII. By February 1641, the Jesuit General Muzio Vitelleschi had not seen the book, but he writes the Flemish Provincial that although he will suspend judgment, he fears that such an ostentatious volume might not be in the best interests of the Society. By June of the same year, Vitelleschi finally reads the book and, in spite of some of its detractors, both he and the censors realized the excellence of the project (Salviucci, 2010: 617-618) ${ }^{11}$ He writes to de Tollenaere: "Opus loculentum est et ad posteros habiturum, ut spero commendationem» (It is a rich work and I hope and it will be acclaimed by posterity). ${ }^{12}$

The first printed Jansenist attack on the Imago comes from a notorious figure, Issac Louis le Maistre de Sacy (1613-84), whose Enluminures du Fameux Almanach des Jesuites (1654) parallel Pascal's opening for the Fifth letter of the Provinciales. ${ }^{13}$

The tenth Enluminure directed against the allegorical figure of "Error» (Jansenist ideas) in the Almanach, mocks a passage from the third book of the Imago, «Societas Agens»: "[...]

11. The publication of the Imago happened at an unauspicious time; see Wright (2011: 178).

12. ARSI, Fl. Belg. 5 Ep. Gen. 990 (cit. in Salviucci, 2004: 201).

13. I have not been able to see the Almanach des Jésuites. This was an illustrated work with large satirical engravings (e.g. XI, the figure of Jansenius dressed as a bishop with wings like a demon escaping the sword of justice and running toward the Calvinists) mocking the jansenists and their proximity to Calvinism. At the beginning of the book, Maître de Sacy describes the engravings which are the subject of the Enluminures. Bound with the Enluminures is also J. Barbier d'Aucur's, Onguant pour la brûlure, o le secret por empecher les Jésuites de brûler les Livres (pp. 99-164) a long poem in huitains with some references to the Imago, but mostly defending Jansenism and attacking the Society and specific Jesuits (Anat, Le Moyne). Also bound in the volume is an anonymous Réponse à la Lettre d'une personne de condition touchant les regles de la conduitte des Saint Pères dans la composition de leur ouvrages [...], pp. 1-112. This segment advocates for establishing ground rules, based on patristic opinions, for attacking Catholic heterodox ideas. 
Angelorum Societas? [...] ut vatis Iessaei oraculo iampridem videri potest pronuntiatum» (Imago: 410). De Sacy's parody in octosyllabic verse reads: "One reads this grand image / where you give honor to yourselves / to this idol of greatness whose temple is in your hearts / one sees that in your praises / you paint yourselves as angels / and the most vain and shameless / will blush at your vanity». ${ }^{14}$

As throughout the history of the reception of the Imago, the editorial elegance, the pride and the perceived bombastic self-congratulatory character of the book always precedes the attacks. The tenth Enluminure continues the satire of the Jesuits by contrasting their self-portrait to their actual performance in the world: "with the weights of a fair scale [...] / there, you wisdom beams forth / here, your baseness is astonishing / there, your heroes are triumphant / here, you are like children / [...] there, you convert the hearts / here you flatter the sinners». ${ }^{15}$

Blaise Pascal criticism of the Imago parallels de Sacy's remarks and it is plausible to presume that he was coached and given all the necessary ammunition for the Provinciales from de Sacy himself, Pierre Nicole (1625-95) and Antoine Arnauld (1612-1694), who was exiled 1656, the same year that the first of Pascal's letters appeared in print. The beginning of the fifth letter opens with: "This is what I have promised (to show you) about the first traits of the moral character of the good Jesuit fathers who are led by divine wisdom which is more certain than any other philosophy». ${ }^{16}$ Although one senses a mocking tone, Pascal assures the reader that he is being serious because he is copying from the Imago.

Pascal continues the satire with: "Jesuits are a society of men, or rather of angels that has been foretold by prophecy. A spirit of eagles a flock of phoenixes, since an author has shown that there are many of those». ${ }^{17}$ This remark about the phoenix is an indirect reference to an emblem of the Imago (580), "Martyrum pretiosa mors" (The precious death of martyrs) with the title "Non poterat fato nobilior mori» (I could not die with a more noble destiny) about Jesuit martyrs [fig. 6]. The emblem displays a pictura of a phoenix burning on its nest, as if in joyful martyrdom, to be born again to eternal life. ${ }^{18}$

It is not by chance that this impresa, with a new inscriptio: "Et benepatientes erunt» (They will endure well), together with that of the palm tree, flank the base of the engraved frontispiece of the Imago. The tree and the bird, due to a lexical coincidence both bear the name phoenix in Latin, represent the birth, growth and service of the Society as well as its lasting fame and renewal through the glory of its martyrs.

Ironically, Pascal laments in one of his manuscripts for Les Provinciales that the Enluminures did a dis-service to the cause of Jansenim; he writes, "Les Enluminures nous ont fait tort» (Pascal, 1970: 140). However, by far the most systematic and virulent attack on the Imago is contained in La Morale pratique des jesuites written by Sébastien Joseph du

14. "Qu'on lis cette altiere Image / Où vous mêmes rendez homage / a cette Idole de grandeur / Dont le temple est dans votre Coeur; / On vous verra dans vos loüanges / Vous dépeindre comme des Anges / Et les vains les plus effrontez / Rougiront de vos vanitez" (Anon. [Issac Louis le Maître de Sacy], 1683: 42).

15. "[...] aux poids d'une juste balance [...]. / Là votre sagesse rayonne / Icy, vostre basstesse estonne / Là, vos Heros sont triomphans / Icy, vous êtes des enfants / [...] Là vous convertissez les coeurs / Icy, vous flattez les pecheurs», Enluminures, 45.

16. "Voici ce que je vous ai promis. Voici les premiers traits de la morale de ces bons Pères Jésuites de ces homes éminents en docrine et en sagesse qui sont tous conduits par la sagesse divine, qui est plus assure que toute la philosophie» (Pascal, 1954: 703).

17. "[...] C'est une societé des hommes, ou plutôt des anges, qui a été predite par Isaïe en ces paroles [...]. Ce sont des esprits d'aigles; c'est un troupe de phénix, un auteur ayant montré depuis peu qu'il y en a plusieurs» (Pascal, 1954: 703).

18. The phoenix as a symbol of change and rebirth had a long run as an emblem motif with different meanings. As a specific symbol of martyrdom, we can cite from Covarrubias, Centuria III, emblem 90, "Foeliciter ardet», that alludes to the martyrdom of St. Lawrence depicting a phoenix in flames on top of an iron grill; St. Lawrence was roasted on a grill. 


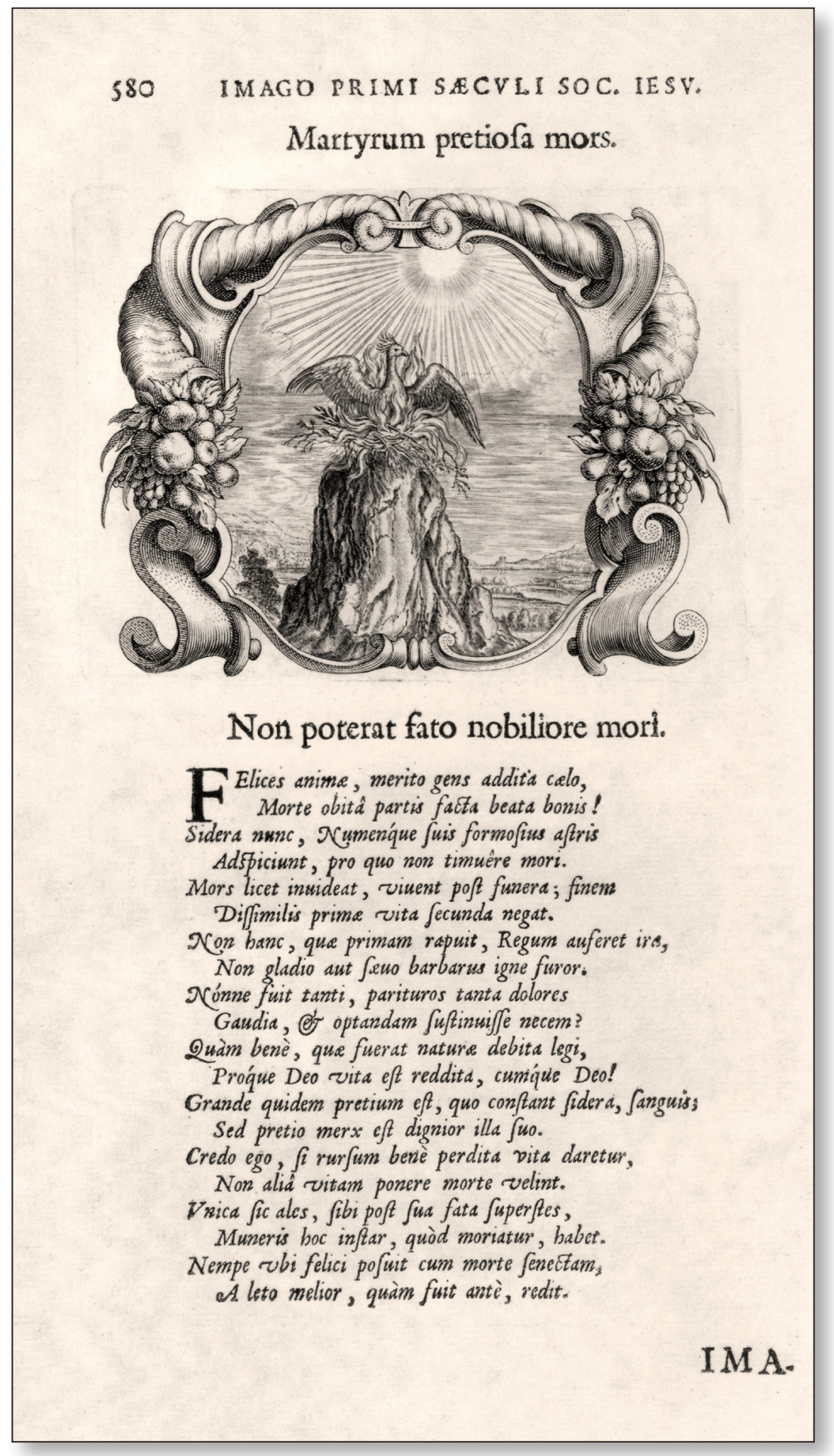

Fig. 6. Imago Primi Saeculi Societatis Iesu (1640). "Liber qvartvs», 580. 
Camboust ${ }^{19}$ l'abbé de Ponchâteau and Antoine Arnauld, anonymously published in Cologne 1669 and again in 1682 (although this might be a fictitious place of publication for a city in the Netherlands). The imprint was originally attributed to Arnauld, but it is really a collaborative volume. La Morale itself deserves a serious study for the history of seventeenth-century propaganda; it is a systematic slanderous critique of the Society since its founding that gathers information, genuine and spurious, from international sources.

As Marc Fumaroli (1994: 365) has pointed out regarding La Morale, translating long segments of the Imago into French illustrates the high-flouting language of the book that becomes a caricature in French translation (Fumaroli, 1994: 495, note 34). La Morale begins listing a number of accusations and calumnies against the Society from the Spanish Dominicans, followed by the controversy of the re-establishment of the Society in France in 1604 and the error of Henri IV to allow the Jesuits to return to France. From pages one to thirty nine the section Extraits du livre intitulé Image du premier siècle de la societé des Jesuites contains a set of quotes in French translation from the Imago, followed by commentary.

The first indictment is that the book exhibits pride, arrogance and self love when it compares the origins and development of the Society with the life of Christ (Morale: 28-30). Other accusations follow: the Jesuits claim to be perfect in wisdom (Morale: 2 ); the Jesuits have no saints who perform miracles because the Society itself is a miracle (Morale: 8); every Jesuit is born with a helmet on his head because they are warriors (Morale: 4); the frontispiece of the Imago reveals the Society as a new foundation of the Church with twelve founders like the twelve apostles (Morale: 19); the founders are compared to emperors, conquerors, great kings and heroes from antiquity (Morale: 23, 30), since all Jesuits are saints they will all be saved (Morale: 33 ). The second (Privileges) and third (Autres Histoires) section ${ }^{20}$ do not concern the Imago, but deal with the privileges enjoyed by the Order and events from other countries relating alleged abuses by Jesuits. These loosely translated quotes from the Imago culminate with the most fierce attack against the very essence of the Society: "the reform that the Jesuits have brought to the Church is that it allows to commit an infinite number of sacrilegious communions, to fill their churches with an infinite number of persons who never leave their confessional without absolution». ${ }^{21}$

The established notion that attacks on the Imago Primi Saeculi were provoked mainly by the ostentatious and self-congratulatory quality of the book are only a small part of the story. The Imago's narrative about the Society's history, detailing the militant opposition from many fronts against their educational and evangelical mission were the cause of the violent animosity against the book. In a sense, the Imago is both an allegoresis of the Society as well as a factual account. As it reads in the prologue, it is a history written with "sweat and blood" ( «sudorem et sanguinem»). The narrative's abundant self-righteousness and lack of diplomacy in recounting the misfortunes of the Society's history must have awakened fresh animosity against the Jesuits given the success of their colleges and their sodalities and their large church attendance.

The Imago was conceived by the organizers as a Jubileum, a celebratory volume (from Latin jubilare, to rejoice). Bollandus drives the point home in his introduction «Dissertationes Prolegomenae de anno saeculari et iubileo" (Imago: 1-24) where he describes the classical origins

19. See Fumaroli (1994: 365, 495); also, Pavone (2010: 229-254).

20. La Morale (1669: 39-137 and 138-201).

21. "[...] toute la reforme que les Jesuites ont aportée dans l'Eglise aboutit à faire commettre une infinité de communions sacrileges, à remplir leurs Eglises d'un nombre infini de personnes qui ne sortent jamais de leurs confessionaux sans absolution [...]", La Morale (1669: 94). 
of the festivities followed by the style of the Jewish and early Christian celebrations and he finishes by describing the last Jubileum for the fiftieth anniversary of the Society commemorated by the Flandro-Belgian Province.

We must presume a certain amount of malice and envy however, since it is important to note that the detractors of the Imago, reputable scholars, philologists and theologians themselves, were not unaware of the classical meaning of Apologia and Jubileum; the Imago is both. It is likely that they had witnessed or participated in formal secular and religious festivities where pomp and circumstance required outlandish visual trappings and florid, hyperbolic oratorical declamations. The encomia of the Society's progress and the virtues of the founders were no more outlandish than the celebratory volumes about the founders of other religious orders or the celebratory programs for the canonization of a saint. Both Marc Fumaroli and Lydia Salviucci have pointed out that the style of the Imago with its oratorical Latin rhetoric, its hyperbole, allegories and symbolic language clashed with the more simple, witty, artful style in vogue at the beginnings of French Classicism, hence it was not difficult to ridicule it.

However, there were other issues, the Jesuit taste for ceremony and spectacle clashed with Jansenism which preferred austere, primitive forms of devotion and simple places of worship. In La Morale, the authors bemoan the fact that «Jesuits with pomp and spectacles fill up their churches, boasting of attracting many faithful», unlike "Cartusians and other orders who have nothing in their churches that can distract them, or that are capable of charming their eyes and ears while leaving their souls dry and worthless». ${ }^{22}$ The Jesuits, according to La Morale transformed their churches from a «house of prayer and penance into a place of voluptuousness and amusement where they often performed plays and tragedies in a very profane and secular manner». ${ }^{23}$

Above all, the Imago is an apologia that is meant to take the elogii as well as the self deprecations to the extreme; such as calling itself a Society "created under the sign of a divine oracle» or referring to itself as "Minimae Societas» ("La plus petite Societé»). What appears to be false modesty is a formal defense of the beliefs and accomplishments of the Society that required a grand-eloquent exaggerated style and the apologia was the formal medium for the defense of the Faith and the Order.

The Imago was an easy target for the enemies of the Society to settle old scores. Issues such as the pretentiousness of the name Societas Iesu, ${ }^{24}$ dispensation from communal prayer, and the fourth vow of papal obedience resurfaced when these issues seemed to have been forgotten since the days of the founding. It must be noted that in the midst of the controversies surrounding the Imago, the Society continued to wield power in high places. One of the first books published by the newly established Royal Press in France in 1640 (Typographia Regia), perhaps fostered by Sublet de Noyers, was an edition of St. Ignatius' Spiritual Exercises. ${ }^{25}$

The Imago Primi Saeculi remains a monument of editorial excellence and the printer's art as well as one of the most interesting emblem books of the seventeenth century. In spite of

22. "[...] des pompes $\theta$ des spectacles don't ils remplissent leurs Eglises. On sçait qu'il font gloire d'y attirer le monde [...]", "[...] comme les Chartreux $\theta$ plusieurs autres Religieux n'ont rien dans leurs Eglises qui les dissipe, et qui soit capable en ravissant leurs yeux $\theta$ leurs oreilles de laisser leur esprit dans la secheresse $\theta$ l'inutilité», La Morale (1669: 96 and 98).

23. "[...] ils font d'une maison de prière et de penitence un lieu de volupté $\theta$ de divertissement. Ils y joüent meme assez souvent des tragedies $\theta$ des comedies d'une manière très profane $\theta$ très seculière [...]", La Morale (1669: 97).

24. La Morale (1669: 41) is quick to point out that the name Societas Iesu was censored by the Faculty of La Sorbonne by "unanimi consensus» in 1554 and not only by some Doctors of the Sorbonne as the Jesuits claimed to have been.

25. Excercitia Spiritualia S.P. Ignatii (Paris, Typographia Regia, 1644), cit. in Birely (2003: 182).

IMAGO, NÚM. 9, 2017, 55-7| 
its controversial aspects, the Imago directly inspired other illustrated Jesuit works that recount with the same intensity the life and missionary works of the members of the Society. For example, parts of Mathias Tanner's (1630-1692) Societas Iesus ad sanguinis et vitae profusionem (Prague, 1675) and Societas Iesu apostolorum imitatrix [...] (Prague, 1694), and Daniello Bartoli's (1608-1685) Della vita e dell'istituto di S. Ignatio [...] (Rome, 1659) accounts of the Society's history drew some inspiration from the Imago. In these works the Jesuits' activities in every day life are depicted, as well as scenes that illustrate the torture and death of their martyrs. In addition, the after life (Van Vaeck, van Houdt and Roggen, 2015: 181-196) of the Imago as a source for other emblem books, as well as the extra-literary use of the Imago inspired on the emblems has been discovered in decorative programs in Jesuit Churches.

\section{SELECTED BIBLIOGRAPHY}

Antwerp Jesuit College [1640]. Imago Primi Saeculi Societas IESU Flandro Belgica Eiusdem Societatis Repraesentata, Antwerpiae, Ex Officina Plantiniana. Balthasaris Moreti, Anno Societatis Saecularis M.DC.XL.

Arnauld, A. [1644]. De La Frequente Communion [...], Paris, Antoine Vitré.

Anon. [Antoine Arnauld et l'Abbé de Ponchâteau] [1669]. La morale pratique des jesuites representée en plusieurs histoires arrivées dans toutes les parties du monde [...], Cologne, Chez Gervinus Quentel. [The second edition: Nancy, Joseph Nicolai, 1682].

Anon. [Issac Louis le Maître de SAcy] [1683]. Les Enluminures du Fameux Almanach des PP. Jesuites Intitulé la Deroute et la Confusion des Jansenistes [...], Liège, Jacques Le Noir.

Arbizzoni, G. [2007]. «Imprese as Emblems: the European Reputation of an 'Italian' Genre», in D. Mansueto (ed.), The Italian Emblem. A Collection of Essays, Glasgow Emblem Studies, $12,1-31$.

Bergin, J. [2009]. Church, Society and Religious Change in France 1580-1730, New Haven, Yale University Press.

Bertram Hill, H. (ed.) [1961]. The Political Testament of Cardinal Richelieu, Madison, The University of Wisconsin Press.

Birely, R. [2003]. The Jesuits and the Thirty Years War. Kings, Courts and Confessors, Cambridge, University Press.

Borromée, C. [1672]. Avis donnez aux confesseurs [...] Imprimez par le commandement de Monseig, l'Archevéque de Paris. Pour les missionaires de son diocese, Lyon, Claude Bachelu.

Brodrick, J. [1928]. The Life and Works of Blessed Robert Bellarmine, London, Burns and Oates, II.

CAmpa, P. F. [1996]. «La génesis del libro de emblemas jesuita», in S. López Poza (ed.), Actas del Congreso Internacional de Emblemática, A Coruña, Universidade da Coruña, 42-60.

Chorpenning, J. [2007]. "Francis de Sales and the Emblematic Tradition: The Palm Tree as an Allegory of St. Joseph's Virtues", in R. Dekonninck et A. Guideroni-Bruslé (eds.), Emblemata Sacra, Rhétorique et Herméutique du Discours dans la Littérature en Images,. Turnhout, Brepols [Imago Figurata, 7], 333-347.

Covarrubias, S. de [1610]. Emblemas morales, Madrid, Luis Sánchez.

Conley S. J., J. [2009]. Adoration and Annhihilation. The Convent Philosophy of Port Royal, Notre Dame, University of Notre Dame Press.

Crétineau-Joly, J. [1846]. Histoire religieuse, politique et littéraire de la Compagnie de Jésus, Tournai, J. Casterman, II. 
De Backer, A. and Sommervogel, C. [1890]. Bibliothèque des Ecrivains la Compagnie de Jésus, Paris, Schepens, I.

Daly, P. M. and Dimler, G. R. (eds.) [1997]. Corpus Librorum Emblematum. The Jesuit Series. Part One, Montreal, Mc Gill Queen's University Press.

Daly, P. M. and Dimler, G. R. [2016]. The Jesuit Emblem in the European Context, Philadelphia, SJUP [Early Modern Catholicism and the Visual Arts, 14].

Díaz de Bustamante, J. M. [1980]. "Onerata Resurgit. Notas a la tradición simbólica y emblemática de la palmera», Helmantica, 31, nºs 94-95, 27-88.

Dimler, G. R. [1981]. "The Imago Primi Saeculi: the Secular Tradition and the Seventeenth-Century Jesuit Emblem Book», Thought, 56 (223), 433-38.

- [1999]. "Jakob Masen's Critique of the Imago Primi Saeculi», in J. MAnning and M. VAN VAECK (eds.), The Jesuits and the Emblem Tradition, Turnhout, Brepols [Imago Figurata, 1A], 279-295.

Domínguez, J. M. and O’Neill, C. [2001]. Diccionario Histórico de la Compañía de Jesús. Biográfico Temático, Madrid / Rome, Universidad de Comillas / IHSI, 4 vols.

Favre, P. [1873]. Memoriale Beati Petri Fabri. Primi S. Ignatii de Loyola alumni, M. BouIx (ed.), Paris, Gauthier-Villars.

Galera Andreu, P. A. [1985]. "La palmera, arbor victoriae. Reflexiones sobre un tema emblemático», Goya, 187-188, 63-67.

Fumaroli, M. [1994]. «Baroque et Classicisme: L'Imago Primi saeculi Societatis Jesu (1640) et ses adversaires", in L'Ecole du Silence. Le Sentiment des Images au xvie Siècle, Paris, Flammarion, 365-395.

Le Bachelet, X. M. [1951]. Prédestination et grâce efficace. Controversies dans la Compagnie de Jésus au temps d'Acquaviva, Louvain, Museum Lessianum, 2 vols.

Martin, A. L. [1988]. The Jesuit Mind. The Mentality of an Elite in Early Modern France, Ithaca, Cornell University Press.

Nelson, E. [2005]. The Jesuits and the Monarchy. Catholic Reform and Political Authority in France (1590-1615), Aldershot, Ashgate [Bibliotheca IHSI 58].

O' Malley, J. (ed.) [2015]. Art Controversy and the Jesuits. The Imago Primi Saeculi (1640), Philadelphia, SJUP [Early Modern Catholicism and the Visual Arts, 12].

Pascal, B. [1954]. Les Provinciales. Cinquième Lettre, in J. Chevalier (ed.), Oeuvres Complètes, Paris, Gallimard (La Pléiade).

- [1970]. Les Provinciales, P. Sellier (ed.), Paris, Nouveaux Classiques Larousse (Documentation Thématique).

Pavone, S. [2010]. «Giano Bifronte: La Compagnia di Gesù tra Imago primi saeculi (1640) e antijesuitismo secentesco", in T. M. McCoog (ed.), Ite inflammate Omnia. Selected Historical Papers from a Conferences Held at Loyola and Rome in 2006, Roma, IHSI (BIHSI, vol. 72), 229-254.

SAlviucci Insolera, L. [2004]. L'Imago Primi Saeculi (1640) e il significato dell'immagine nella Compagnia di Gesù. Genesi e fortuna del libro, Rome, Editrice Pontificia / Università Gregoriana.

- [2010]. "L'Imago Primi Saeculi tra Anversa e Roma», Gregorianum, 91, 3, 606-19.

Strayer, B. E. [2012]. Suffering Saints. Jansenists and Convulsionaries in France, 1640-1799, Brighton, Sussex Academic Press.

Van Vaeck, M., van Houdt, T. and Roggen, L. [2015]. "The Imago Priimi Saeculi Societatis Jesu as Emblematic Self-Presentation and Commitment», in J. O' Malley (ed.), Art Controversy and the Jesuits. The Imago Primi Saeculi (1640), Philadelphia, SJUP [Early Modern Catholicism and the Visual Arts, 12], 127-410.

Wright, A. [2011]. The Divisions of French Catholicism, 1629-1645. The Parting of the Ways, Surrey, Ashgate.

IMAGO, NÚM. 9, 20 I 7, 55-7I 
